\title{
Effect of human parathyroid hormone on the CAMP production and the endocrine functions of trophoblast cells from first trimester placenta
}

\author{
M Dodeur 1, A Mensier 1, E Alsat 1, \\ D Bellet 2, JM Bidart 2, D Evain-Brion 1* \\ 1 CNRS-URA 1337, ENS, Laboratoire de Physiopathologie du Développement, \\ 46 rue d'UIm, 75230 Paris Cedex 05; \\ 2 Institut Gustave Roussy, Département de Biology Clinique, 94805 Villejuif, France
}

(Received 5 December 1990; accepted 14 February 1991)

\begin{abstract}
Summary - Our previous study on teratocarcinoma cells suggested the role of human parathyroid hormone (hPTH) in early development of the placenta. The purpose of this study was to evaluate the possible role of hPTH on the functions of first trimester trophoblast cells. Adenylate cyclase activity in crude membranes from first trimester human placental villous tissue is stimulated 2-fold by hPTH (1-34) $\left(10^{-6} \mathrm{~mol}^{-1} \mathrm{I}^{-1}\right)$ from $265 \pm 32$ to $532 \pm 80 \mathrm{pmol}$ of $\mathrm{cAMP} / \mathrm{mg}$ protein $/ 15 \mathrm{~min}$. A similar stimulation of adenylate cyclase is observed in human term placental villous tissue but not in 3 different choriocarcinoma cell lines.

In order to evaluate the possible role of hPTH on the functions of first trimester human trophoblast cells, these cells were isolated by dispase and cultured $\left(2 \times 10^{5}\right.$ cells per plate) in DMEM supplemented with $20 \%$ fetal calf serum with or without $100 \mathrm{ng} / \mathrm{ml}$ of epidermal growth factor (EGF), for 4 d. On d 2 of culture, hPTH $\left(10^{-7}\right.$ mol..$\left.^{-1}\right)$ stimulates cAMP production of these cells from $0.52 \pm 0.2$ to $2.58 \pm 0.57$ pmol.h $\mathrm{h}^{-1}$ per $10^{6}$ cells (mean \pm SEM). As compared to control $(30 \mathrm{ng} / \mathrm{ml})$, the output of hCG is increased by $1.5-$ (NS), 2- $(P<0.01)$ and $3-(P<0.01)$ fold by EGF, hPTH, and hPTH added with EGF, respectively. Dibutyryl CAMP $\left(10^{-3} \mathrm{~mol}^{-1} \mathrm{I}^{-1}\right)$ increased hCG secretion by 3 -fold $(P<0.05)$. EGF and hPTH added separately or together significantly stimulated $(P<0.01)$ the secretion of free $\alpha$ subunit 2-fold from $35 \mathrm{ng} / \mathrm{ml}$ to $70 \mathrm{ng} / \mathrm{ml}$. in contrast, hPTH and EGF added separately did not change the secretion of free $\beta$ hCG. However, added together, they significantly increased $(P<0.01)$ the secretion of free $\beta$ hCG after $48 \mathrm{~h}$ of culture, maximal stimulation (2.5 fold) being observed at $\mathrm{d} 4$ of culture. In conclusion, human trophoblast cells are target cells for hPTH. hPTH acts in association with EGF in promoting expression of endocrine activity of these cells, such as hCG secretion. Trophoblast cells provide a model for the study of the cooperative effect between a peptide hormone and a growth factor in the regulation of endocrine function.
\end{abstract}

human placenta / parathyroid hormone / cAMP / trophoblast secretions

Résumé - Effet de la parathormone humaine sur la production d'AMPc et sur les fonctions endocrines des cellules trophoblastiques de placenta du $1^{\mathrm{er}}$ trimestre. Notre précédente étude sur les cellules de tératocarcinome suggérait que la parathormone humaine (hPTH) jouait un rôle sur le développement précoce du placenta. Le but de la présente étude était d'évaluer le rôle pos-

\footnotetext{
* Correspondence and reprints
} 
sible de la hPTH sur les fonctions des cellules trophoblastiques du premier trimestre. L'activité de l'adénylcyclase dans les membranes issues de villosités humaines placentaires du fer trimestre est doublée par la hPTH (1-34) $\left(10^{-6} \mathrm{~mol}^{-1} \mathrm{t}^{-1}\right)$ de $265 \pm 32$ à $532 \pm 80$ pmol d'AMPc par mg de protéines/ $15 \mathrm{~min}$. Une stimulation identique de l'adénylcyclase est observée dans le tissu de villosités de placenta humain à terme, mais pas dans 3 lignées cellulaires différentes de choriocarcinomes. Afin d'évaluer le rôle possible de la hPTH sur les fonctions des cellules humaines du trophoblaste du $1^{e r}$ trimestre, de telles cellules ont été isolées par de la dispase et cultivées $\left(2.10^{5}\right.$ cellules/boîte) dans du DMEM supplémenté en sérum de veau foetal (20\%) et en facteur de croissance épidermique (EGF) $(100 \mathrm{ng} / \mathrm{ml})$, sauf pour les témoins, pendant $4 \mathrm{j}$. Le $2^{\circ}$ jour de la culture, la $\mathrm{hPTH}\left(10^{-7} \mathrm{~mol} . \mathrm{r}^{-1}\right)$ stimule la production d'AMPc de ces cellules de 0,52 $\pm 0,2$ a 2,58 $\pm 0,07$ pmol. $\mathrm{r}^{-1}$ pour $10^{6}$ cellules (moyenne \pm écart type). Par rapport à la production des cellules témoins ( $30 \mathrm{ng} / \mathrm{ml})$, la production de hCG est multipliée respectivement par 1,5 (NS), $2(\mathrm{P}<0,01)$ ou 3 ( $<<0,01$ ), par la présence d'EGF, de hPTH, ou de $h P T H+$ EGF. Le dibutyryl AMPC $\left(10^{-3}\right.$ mol..$\left.^{-1}\right)$ multiplie le taux de sécrétion de hGC par $3(\mathrm{P}<0,05)$. L'EGF et l'hPTH ajoutés séparément ou simultanément stimulent significativement $\mathbf{P}<$ $0,01)$ la sécrétion de la sous-unité $\alpha(x 2)(70 \mathrm{ng} / \mathrm{m} /$ contre $35 \mathrm{ng} / \mathrm{ml})$. En revanche, la hPTH et l'EGF ajoutées séparément ne changent pas la sécrétion de la $\beta$ hCG libre. Cependant, ajoutés ensemble, ils augmentent significativement $(\mathrm{P}<0,01)$ la sécrétion de la $\beta$ hCG libre après 48 h de culture, la stimulation maximale $(x 2,5)$ étant observée au $4^{\theta}$ jour de la culture. En conclusion les cellules trophoblastiques humaines sont des cellules cibles pour la hPTH. La hPTH agit en association avec l'EGF pour promouvoir l'expression des activités endocrines de ces cellules telle que la sécrétion de la hCG. Les cellules trophoblastiques fournissent un modèle pour l'étude de l'effet coopératif entre une hormone peptidique et un facteur de croissance sur la régulation d'une fonction endocrine.

placenta humain / hormone parathyrö̈dienne / AMPC / sécrétion trophoblastique

\section{INTRODUCTION}

Human chorionic gonadotropin (hCG) is a placental glycoprotein hormone necessary for the maintenance of pregnancy (Simpson and Mac Donald, 1981). The production of hCG is highest and of greatest significance in early pregnancy, but little is known of the factors regulating the production of this hormone at the present time.

The approach to these questions has been facilitated by culturing human trophoblast cells (Kliman et al, 1986, 1987). Isolated by enzymatic digestion from the villous tissue, the mononuclear cytotrophoblasts cultured in vitro aggregate and through cell fusion form a syncytiotrophoblast with specifc functions (Kliman et al, 1986).

The secretion of hCG is increased in vitro by 8-bromo-cAMP (Feinman et al, 1986; Ulloa-Aguirre et al, 1987). This cAMP analogue promotes hCG synthesis by increasing the mRNA levels encoding the $\alpha$ and $\beta$ subunits of the hormone (Jameson et al, 1986). In addition, activation of the adenylate cyclase by cholera toxin or forskolin increases the hCG secretion by human cytotrophoblasts from term placenta (Nulsen et al, 1988).

Epidermal growth factor (EGF) is a polypeptide of $6040 \mathrm{Da}$, isolated from mouse submaxillary glands (Cohen, 1962) and human urine (Cohen and Carpenter, 1975). Receptors for EGF have been described predominantly on the syncytiotrophoblasts in term placenta (Maruo et al, 1987) and on the membranes of purified trophoblast cells in early and term placentas (Chen et al, 1988; Mirlesse et al, 1991). In addition, EGF has been reported to influence the differentiation of human cytotrophoblasts in culture (Truman and Ford, 1986). The effects of EGF on hCG secretion described in mid-term or full-term organ cultures are conflicting; Lai and Guyda (1984) reported hCG secretion stimulated by EGF, whereas Huot et al (1981) observed no such effect. 
Murine teratocarcinoma cells differentiate in vitro following the first step of embryogenesis (Martin, 1980). They offer a model to study the role of polypeptide hormones during early embryogenesis. Thus, adenylate cyclase activity of these parietal endoderm cells in culture is stimulated by parathyroid hormone (PTH) (Evain Brion et al, 1981; Liapi et al, 1987). These previous results suggested a role for this hormone in placental development. In agreement with this hypothesis, recent studies demonstrate that the human placenta is a target organ for PTH as shown by the characterization of a specific receptor for PTH in purified membranes from term placenta (Lafond et al, 1988).

The purpose of this investigation was therefore the determination of the effect of PTH on the endocrine functions of trophoblast cells from first trimester placenta. In this study we demonstrate that human trophoblast cells from early gestation are specific target cells for PTH. Indeed, PTH stimulates adenylate cyclase activity of trophoblast cell membrane and fails to stimulate the adenylate cyclase activity of membranes isolated from either cultured choriocarcinoma or placental mesenchymal cells. Moreover, PTH together with EGF stimulates the secretion of hCG, and modulates the secretion of free $\alpha$ and $\beta$ subunits to a different extent, as measured by specific monoclonal immunoradiometric assays.

\section{MATERIALS AND METHODS}

First-trimester placentas were obtained from voluntary elective abortions at 6 to $12 \mathrm{wk}$ of amenorrhea, and term placentas from spontaneous full-term deliveries. Placental villous tissues were dissected free of chorionic membranes and incubated at $4{ }^{\circ} \mathrm{C}$ for $1 \mathrm{~h}$ in phosphatebuffered saline $\mathrm{pH} 4.7(\mathrm{NaCl} 137 \mathrm{mM}, \mathrm{KCl} 3$ $\mathrm{mM}, \mathrm{Na}_{2} \mathrm{HPO}_{4} 8 \mathrm{mM}, \mathrm{KH}_{2} \mathrm{PO}_{4} 1.5 \mathrm{mM}$ ) contain- ing $100 \mu \mathrm{g} / \mathrm{ml}$ gentamycin and $2.5 \mu \mathrm{g} / \mathrm{ml}$ amphotericin.

\section{Cell isolation, characterization and culture}

Trophoblast cells were isolated by using a previously described dispase dispersion method (Dodeur et al, 1990). The villous tissue was incubated with a solution of dispase $(2.4 \mathrm{U} / \mathrm{ml})$, a neutral protease from Bacillus polymyxa (EC 3.4.24.4) in Puck's solution (BoerhingerMannheim) for $3 \mathrm{~h}$ at $4^{\circ} \mathrm{C}$. Afterwards the dispase solution was discarded and the tissue incubated overnight in medium A: DMEM containing $25 \mathrm{mM}$ glucose, $4 \mathrm{mM}$ glutamine, $25 \mathrm{mM}$ HEPES, $100 \mu \mathrm{g} / \mathrm{ml}$ gentamycin, $2.5 \mu \mathrm{g} / \mathrm{ml}$ amphotericin (Seromed Biochrom, Lyon, France) and $20 \%$ heat-inactivated fetal calf serum (Biological industries) in humidified $5 \% \mathrm{CO}_{2}$ and $95 \%$ air at $37^{\circ} \mathrm{C}$.

Trophoblast cells were spontaneously released from villous tissue into the medium. The trophoblast cells were plated at $2.5 \times 10^{5}$ cells/ per $35 \mathrm{~mm}$ plates coated with human fibronectin ( $1 \mathrm{mg} / \mathrm{ml}$, Sigma). At $24 \mathrm{~h}$ of culture, cytotrophoblast cells were positively immunostained by antibodies against cytokeratin (Pan cytokeratin, undiluted antibody, Amersham-France) and against $\alpha$ hCG (Mab 326-2-1, Immunotech). Cells were treated with these antibodies at appropriate dilutions and then with biotinylated secondary antibodies (Amersham-France), the binding of which was visualized with an avidinbiotin-peroxidase complex detection method (Hsu and Raine, 1981). The avidin-biotinperoxidase complex detection kit was purchased from Amersham (France). In contrast, no immunostaining was obtained using the same methodology and a monoclonal antivimentin antibody (undiluted, AmershamFrance). At $72 \mathrm{~h}$ of culture, multinucleated syncytiotrophoblast was predominant as studied by electron microscopy.

Mesenchymal cells were obtained from undigested villous tissue by explant cultures; these cells were grown in medium $A$ and used to their second or third passages.

The choriocarcinoma cell lines JAR, JEG, BEWO, were cultured as previously reported (Patillo and Gey, 1968; Patillo et al, 1971). 


\section{Secretion of hCG by trophoblast cells in culture}

Trophoblast cells were cultured during $96 \mathrm{~h}$ in medium A with or without EGF $(100 \mathrm{ng} / \mathrm{ml}$, Collaborative Research), human PTH (hPTH)1-34 $\left(10^{-6} \mathrm{M}\right.$, a generous gift of Rorer Laboratory, Levallois, France), hPTH plus EGF, or dibutyryl cAMP $\left(10^{-3} \mathrm{M}\right.$, Sigma). The medium was changed daily and stored at $-80^{\circ} \mathrm{C}$ until analyzed.

\section{Crude membrane preparation}

Cultured cells were washed with ice-cold buffer (50 mM Tris- $\mathrm{HCl}, \mathrm{pH} 7.8,0.33 \mathrm{M}$ sucrose, $1 \mathrm{mM} \mathrm{MgCl} 2$ ), harvested by scraping and homogenized by 20 strokes with a Dounce homogenizer. Homogenates were centrifuged at $12000 \mathrm{~g}$ for $20 \mathrm{~min}$ at $4{ }^{\circ} \mathrm{C}$ to isolate crude membranes. Placental villous tissue was cut in small pieces and homogenized by 50 strokes in the ice-cold buffer as described above.

\section{Adenylate cyclase activity}

Adenylate cyclase activity was determined by measuring the conversion of $\left[\alpha^{32} \mathrm{P}\right]-\mathrm{ATP}$ (Amersham) to [32P]-cAMP in crude membranes (12 $000 \mathrm{~g}$ pellet) at $37^{\circ} \mathrm{C}$ as previously described (Evain Brion et al, 1981). The standard incubation mixture contained $25 \mathrm{mM}$ Tris- $\mathrm{HCl}$, $\mathrm{pH} 7.8,10 \mathrm{mM}$ phosphoenolpyruvate, $4 \mu \mathrm{g}$ of pyruvate kinase, $5 \mathrm{mM} \mathrm{MgCl}_{2}, 0.2 \mathrm{mM}$ ATP, 0.5 mM EGTA, $4 \times 10^{6} \mathrm{cpm}\left[\alpha^{32} \mathrm{P}\right]-A T P$ and $50 \mu \mathrm{g}$ of membrane protein. The hormonal stimulation by human PTH (hPTH) 1-34 (10-6 M) was measured in presence of $10^{-5} \mathrm{M}$ GTP. The effect of PTH analog (Nle8-18 $\mathrm{Tyr}^{34}$ ) PTH 3-34 amide (Boerhinger-Mannheim) was tested in 10-fold excess as compared to hPTH 1-34.

\section{Determination of CAMP in the culture medium}

After acetylation, cAMP was measured by a specific radioimmunoassay in the culture medi- um (Steiner et al, 1972). cAMP antibody was a generous gift of J Saez (Inserm U 307, Lyon, France).

\section{Determination of $h C G$ and its free $\alpha$ and $\beta$ subunits}

MAb-based specific IRMAs were used for the determination of hCG (Bellet et al, 1986), $\alpha$ hCG and $\beta$ hCG (Ozturk et al, 1987) levels in cell culture media. The production of MAbs with defined epitope specificity, the development of multisite IRMAs and the testing of their specificty have been previously described (Bellet et al, 1986; Ozturk et al, 1987).

\section{Protein concentration}

Protein concentration was determined by the method of Bradford (1976).

\section{Statistical analysis}

Statistical analysis of the data was carried out by the paired Student's $t$-test to compare the effects of the added factors to the effect of fetal calf serum (FCS) alone at each time.

\section{RESULTS}

\section{Effect of PTH on placental adenylate cyclase activity}

Adenylate cyclase activity was assayed in membranes prepared from either villous tissue (crude membranes) from early gestation and term placenta, or cultured cells from first trimester placenta and from choriocarcinoma cell lines. The results are summarized in table I. PTH $\left(10^{-6} \mathrm{M}\right)$ induced a significant increase $(P<0.025)$ in adenylate cyclase activity of crude membranes from first trimester and full-term placenta, 
Table l. Effect of hPTH (1-34) on adenylate cyclase activity of placental villous tissue and cultured cell membranes.

\begin{tabular}{lrrrrr}
\hline Basal & $\begin{array}{c}\text { GTP } \\
10^{-5} \mathrm{M}\end{array}$ & $\begin{array}{c}\mathrm{NaF} \\
10^{-2} \mathrm{M}\end{array}$ & $\begin{array}{c}\text { PTH } \\
10^{-6} \mathrm{M}\end{array}$ & $\begin{array}{c}\text { PTH } \\
\text { antagonist }\end{array}$ \\
\hline Villous tissue & & & & & \\
$\quad$ 1st trimester & $201 \pm 22$ & $265 \pm 32$ & $1093 \pm 100$ & $532 \pm 80^{*}$ & \\
Term & $154 \pm 25$ & $202 \pm 27$ & $1620 \pm 140$ & $338 \pm 33^{*}$ & \\
& & & & & \\
Cultured cells & & & & & \\
$\quad$ Mesenchymal cells & $515 \pm 90$ & $644 \pm 100$ & $2320 \pm 386$ & $644 \pm 40$ & \\
Trophoblastic cells & $140 \pm 15$ & $185 \pm 20$ & $940 \pm 100$ & $270 \pm 20^{*}$ & $180 \pm 10$ \\
JAR cells & $57 \pm 10$ & $80 \pm 10$ & $1700 \pm 180$ & $90 \pm 20$ & \\
JEG cells & $30 \pm 12$ & $50 \pm 20$ & $646 \pm 100$ & $52 \pm 20$ & \\
BEWO cells & $69 \pm 10$ & $90 \pm 25$ & $1230 \pm 150$ & $90 \pm 25$ & \\
\hline
\end{tabular}

Enzyme activity was measured as described in Materials and Methods with GTP $\left(10^{-5} \mathrm{M}\right)$. GTP $\left(10^{-5} \mathrm{M}\right)+\mathrm{hPTH}$ $\left(10^{-6} \mathrm{M}\right)$. PTH antagonist (Nle $\left.{ }^{8-18} \mathrm{Tyr}^{34}\right)$ PTH 3-34 was tested in 10-fold excess as compared to hPTH 1-34. The results are expressed in pmol of cAMP/mg of protein $/ 15 \mathrm{~min}$ and are the means \pm SD of triplicate incubations from 3 different experiments. Values ${ }^{*}$ are significantly greater than control values (GTP $\left.10^{-5} \mathrm{M}\right),(P<0.025)$.

as compared to corresponding control values (GTP $10^{-5} \mathrm{M}$ ). Similar results were observed for PTH effect on membrane adenylate cyclase activity of isolated trophoblastic cells, cultured for $2 \mathrm{~d}(P<$ 0.025). The specificity of this stimulation was demonstrated using a PTH analog (Nle $8-18 \mathrm{Tyr}^{34}$ ) PTH (3-34) amide -able to compete with the PTH receptor- which fails to stimulate the adenylate cyclase activity in membranes from cultured trophoblastic cells. Furthermore, in comparison with control values (GTP $10^{-5} \mathrm{M}$ ), the enzyme activity was not modified by PTH in membranes from placental mesenchymal cells and from 3 different choriocarcinoma cell lines (JAR, JEG and BEWO), indicating that PTH-induced stimulation of adenylate cyclase was specific for normal trophoblastic cells.

In addition, as shown in figure 1, PTH stimulated CAMP production by intact isolated trophoblast cells in culture. The effect was dose-dependent with a maximal stimulation $\left(\approx 5\right.$-fold) occurring at $10^{-7} \mathrm{M}$ of hPTH $(P<0.01)$, as compared to the CAMP production by control cells $(0.50$ $\mathrm{pmol} / 60 \mathrm{~min} / 10^{6}$ cells).

\section{Effect of PTH on hCG secretion by trophoblast cells in culture}

Having demonstrated the PTH stimulated adenylate cyclase activity in the membranes of trophoblast cells, we next determined whether this activation would promote the expression of one endocrine activity of these cells which is stimulable by cAMP, the secretion of hCG.

Trophoblast cells were cultured during $96 \mathrm{~h}$ in the presence of PTH $\left(10^{-6} \mathrm{M}\right)$ or EGF $(100 \mathrm{ng} / \mathrm{ml})$ alone or in the presence of PTH together with EGF and their effect on the secretion of hCG (fig 2) and its free $\alpha$ (fig $3 \mathrm{~A}$ ) and $\beta$ (fig $3 \mathrm{~B}$ ) subunits was stud- 


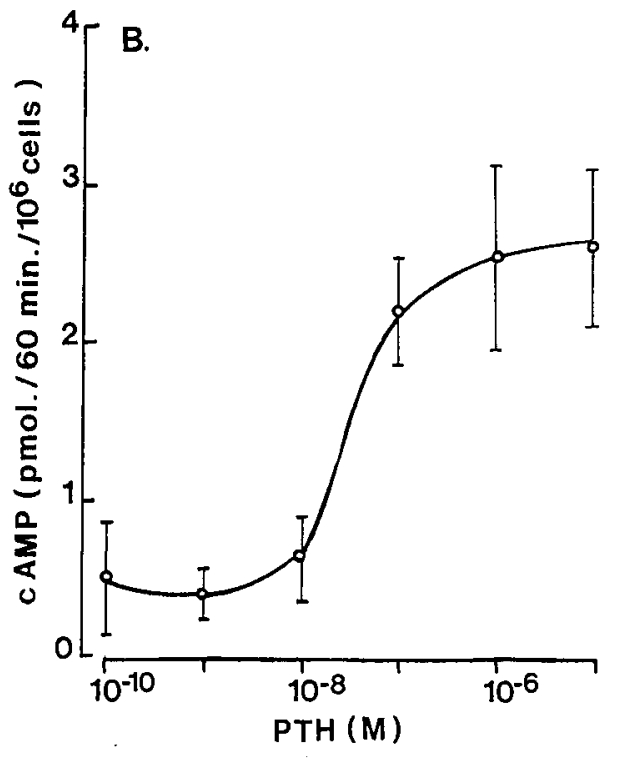

Fig 1. Effect of increasing concentration of PTH (1-34) on the CAMP production by human trophoblast cells in culture. Trophoblast cells isolated as described in Methods were cultured for 2 $d$ in medium $A$. The culture medium was then changed and the cells were incubated in medium $A$ in presence of different concentrations of $\mathrm{hPTH}$. After $1 \mathrm{~h}$ incubation, the medium was collected for cAMP determination. Each value is a mean of triplicate determinations of 2 different experiments (mean \pm SEM).

ied. As compared to control ( $20 \%$ serum supplemented medium), the secretion of hCG or of its free $\beta$ subunits was not significantly modified by EGF at any time of the cell culture. The secretion of free $\alpha$ subunit seemed significantly enhanced by EGF during the first $2 \mathrm{~d}$ of culture. Parathyroid hormone significantly stimulated the secretion of intact hCG and its free $\alpha$ subunit by $\approx 2$-fold $(P<0.01)$ but did not modify the secretion of $\beta$ subunit.

The addition of EGF and hPHT to the culture medium increased by $\approx 3$-fold the secretion of hCG and of its free $\alpha$ subunit during the first $3 \mathrm{~d}$ of culture and in a similar manner to the addition of dibutyryl cAMP $\left(10^{-3} \mathrm{M}\right)$ (fig 2, 3A).

Of interest is the fact that the association of EGF and PTH which did not have any effect on the secretion of $\beta$ subunit during the first $2 \mathrm{~d}$ of culture increased significantly $(P<0.01)$ by $\approx 2$-fold the output of free $\beta$ subunit at 72 and $96 \mathrm{~h}$ of culture (fig 3B).

\section{DISCUSSION}

We have established in this study that human trophoblast cells from early gestation placenta possess an adenylate cyclase activity which is stimulated by hPTH. The specific activity of early gestational adenylate cyclase activity is in the range reported in term placenta villous homogenates (Menon and Jaffe, 1973; Milewich et al, 1982) or in term placenta trophoblast cells in culture (Nulsen ot al, 1988). PTH stimulates CAMP production in intact human trophoblast cells in a dose-dependent manner similar to that reported in other fetal and adult organs (Nissenson and Arnaud, 1979; Silve et al, 1982).

Our results are in agreement with the recent report on: i), the study of adenylate cyclase in the membranes of cultured trophoblast cells from term placenta (Nulsen et al, 1988); and ii), the activity of adenylate cyclase stimulated by PTH in the basal plasma syncytiotrophoblastic membranes of term placenta (Lafond et al, 1988). In addition, PTH stimulates phosphate transport in the placenta (Brunette et al, 1989) and increases the number of EGF receptors in cultured human tropho= blast cells (Alsat et al, 1991). These results suggest that PTH stimulates adenylate cy= clase activity of syncytiotrophoblast cells throughout pregnancy. Moreover, the pres- 


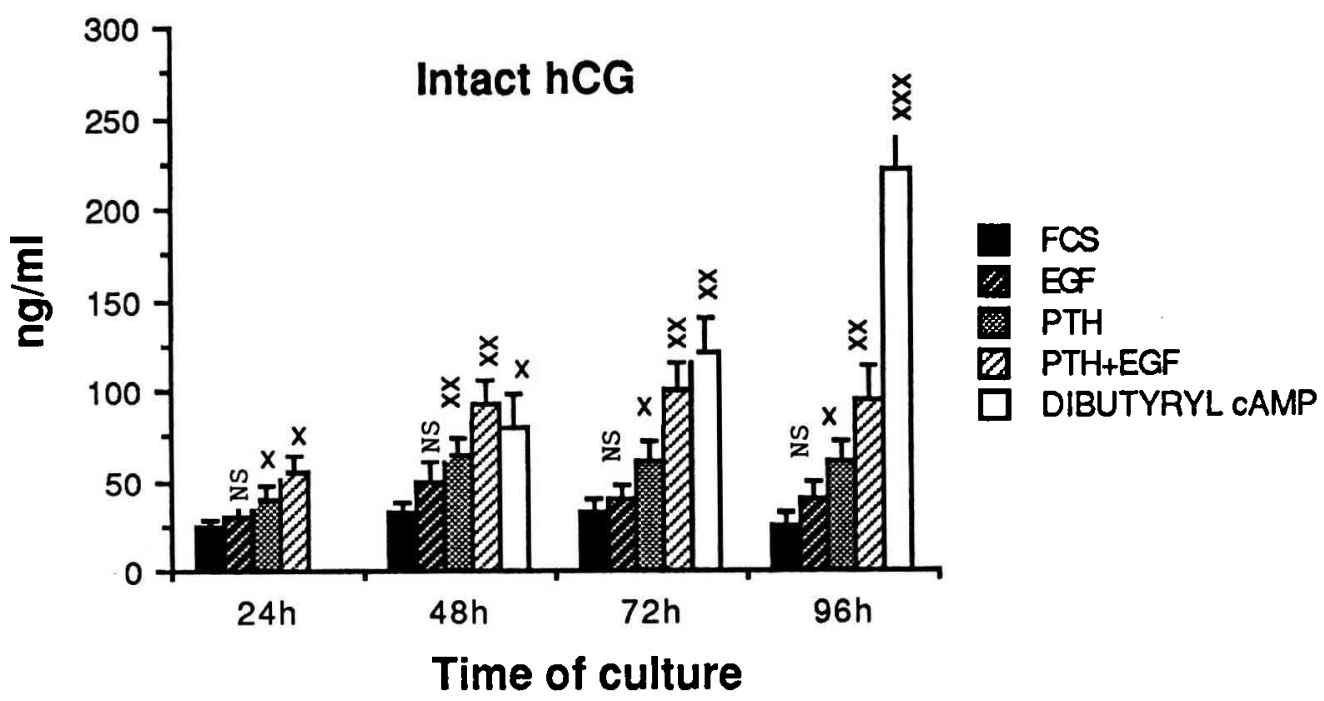

Fig 2. Effect of EGF (100 ng/ml), hPTH $\left(10^{-6} \mathrm{M}\right), \mathrm{hPTH}$ added together with EGF and dibutyryl cAMP $\left(10^{-3} \mathrm{M}\right)$ on hCG secretion by trophoblast cells in culture. The results are expressed as ng of hCG released into $1 \mathrm{ml}$ of medium / $24 \mathrm{~h}$. Each value is the mean \pm SD of triplicate incubations from 5 different experiments. Statistical analysis of the data was carried out by the Student's $t$-test to compare the effects of the added factors to the effect of fetal calf serum alone (control) at each time of cell culture. NS $=$ not significant; $x=P<0.05 ; x x=P<0.01 ; x x x=P<0.001$.

ence of PTH receptors in membranes of trophoblast cells appeared to be specific for the normal cells since we failed to detect any activation in the membranes of 3 choriocarcinoma cell lines.

In this study we also investigated the secretion of hCG and of its free $\alpha$ and free $\beta$ subunits by cultured trophoblast cells. In our experimental conditions the secretion of hCG did not vary significantly from 24 to $96 \mathrm{~h}$ of culture. As compared to control (20\% FCS), EGF alone had no significant effect on the stimulation of hCG secretion. This might be related to the concentration of EGF already present in the fetal calf serum. PTH alone increased significantly $(P<$ 0.01 ) hCG secretion by 2-fold, maximum stimulation being observed at $48 \mathrm{~h}$ of culture. Of interest is the fact that PTH in as- sociation with EGF induced a level of secreted $\mathrm{hCG}$ similar to that obtained by addition of dibutyryl cAMP alone during the mid-stages of the culture (48 and $72 \mathrm{~h}$ ). This result suggested that PTH in association with EGF might have a specific role in the regulation of endocrine functions in trophoblast cells. In contrast, PTH alone or in association with EGF stimulated the secretion of $\alpha$ subunit in a similar way. No stimulation of free $\beta$ subunits was observed during the first 2 days of culture but a significant $(P<0.01)$ increase in free $\beta$ subunits secretion was observed at 72 and $96 \mathrm{~h}$ of culture in the presence of PTH together with EGF.

The apparent synergism of action between PTH and EGF on hCG secretion and especially on its free $\beta$ subunit secre- 

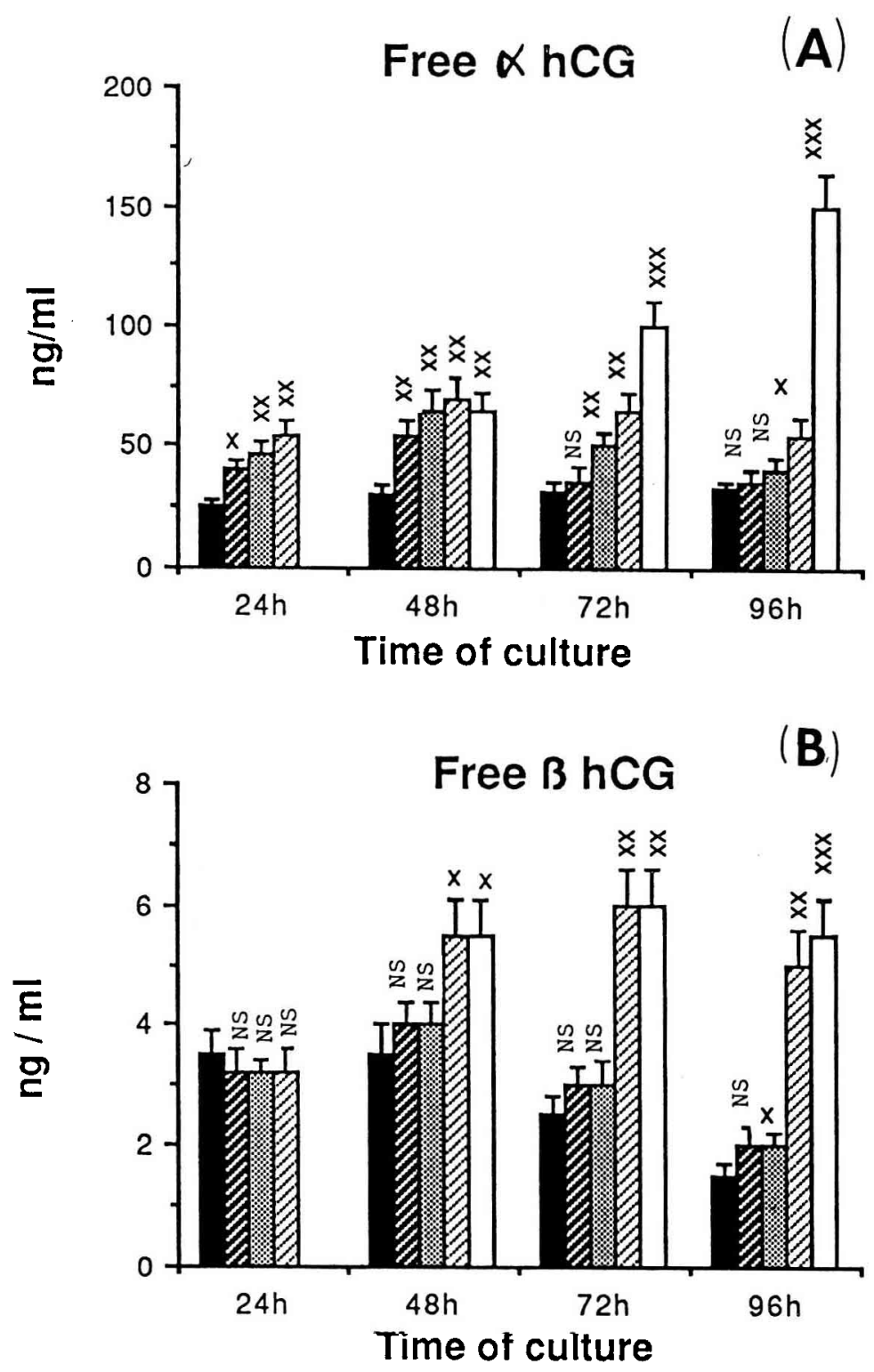

Fig 3. Effect of EGF $(100 \mathrm{ng} / \mathrm{ml})$, PTH $\left(10^{-6} \mathrm{M}\right)$, PTH added together with EGF and dibutyryl cAMP $\left(10^{-3} \mathrm{M}\right.$ ) on the secretion of free $\alpha$ hCG subunit (panel A) and free $\beta$ hCG subunit (panel B) by trophoblast cells in culture. The results are expressed as $\mathrm{ng}$ of hCG subunit released into $1 \mathrm{ml}$ of medium per $24 \mathrm{~h}$. Each value is the mean \pm SD of triplicate incubations from 5 different experiments. The statistical analysis was performed as indicated in the legend of figure 2. 
tion could be related to a synergistic effect at the receptor or post-receptor levels of this growth factor and this hormone. A growth factor may regulate the binding of a specific hormone. For example, PTH alters the TGF $\beta$ binding to its receptors in osteoblast in culture (Centrella et al, 1988). The interaction between hormone and growth factor may also be located at the coupling level of adenylate cyclase (Bernier et al, 1986; Jaillard et al, 1987). It is interesting to note that EGF has been shown to promote the phosphorylation of a protein which appears to be similar to the $G$ protein subunit (Valentine-Braun et al, 1986).

Another explanation could be that PTH potentiated the role of EGF in the differentiation of cytotrophoblast to syncytiotrophoblast. Therefore in presence of PTH and EGF, the cytotrophoblasts which continuously synthesize $\alpha$ subunit became differentiated into syncytiotrophoblasts, more competent to express the $\beta$ subunit of hCG inducing first an increase in hCG secretion followed by secretion of free $\beta$ subunit. This hypothesis is in agreement with the recent report of Hoshina et al (1982) who showed by in situ hybridization different steps in the differentiation of cytotrophoblast into syncytiotrophoblast.

Recently the structure, location, and transcriptional pattern of a PTH-like protein (PTHLP), first described as tumoral products have been revealed (Orloff et al, 1989). This protein shares amino acid sequence homology with PTH and interacts with its receptors in classical target and other tissues. In sheep placenta, partially purified PTHLP appears to stimulate specifically calcium transport in vivo (Rodda et al, 1988) and PTHLP has been detected in human placenta (Asa et al, 1990). In our experimental conditions PTHLP was not significantly more effective than $\mathrm{hPTH}$ in stimulating CAMP production or hCG secretion (data not shown).
In summary, trophoblast cells are a target for PTH. This hormone acts in association with EGF to promote expression of endocrine activities of these cells, such as hCG secretion. Trophoblast cells provide a model for studying the cooperative effect between a peptide hormone and a growth factor in the regulation of endocrine function.

\section{ACKNOWLEDGMENTS}

This work was supported by a grant from La Fondation pour la Recherche Médicale and La Ligue Parisienne contre le Cancer. We would like to thank F Lewin (Hôpital Saint-Vincent-dePaul, Paris) and the staff of the department of gynecology for their cooperation.

\section{REFERENCES}

Alsat E, Mirlesse V, Fondacci C, Dodeur M, Evain-Brion D (1991) Parathyroid hormone increases epidermal growth factor receptors in cultured human trophoblastic cells from early term placenta. J Clin Endocrinol Metab (in press)

Asa SL, Henderson J, Goltzman D, Drucker J (1990) Parathyroid hormone like peptide in normal and neoplastic human endocrine tissues. J Clin Endocrinol Metab 71, 1112-1118

Bellet DH, Ozturk M, Bidart JM, Bohuon CJ, Wands JR (1986) Sensitive and specific assay for human chorionic gonadotropin (hCG) based on anti-peptide and anti-hCG monoclonal antibodies: construction and clinical implications. J Clin Endocrinol Metab 63, 1319-1327

Bernier $M$, Chatelain $P$, Mather JP, Saez JM (1986) Regulation of gonadotropin receptors, gonadotropin responsiveness and cell multiplication by somatomedin $C$ and insulin in cultured pig Leydig cells. J Cell Physiol 129, 257-263

Bradford MM (1976) A rapid and sensitive method for the quantification of microgram quanti- 
ties of protein utilizing the principle of protein-dye binding. Anal Biochem 72, 248-254

Brunette MG, Auger D, Lafond J (1989) Effect of parathyroid hormone on $\mathrm{PO}_{4}$ transport through the human placenta microvilli. Pediatr Res 25, 15-18

Centrella M, Mac Carthy TL, Canalis E (1988) Parathyroid hormone modulates transforming growth factor $\beta$ activity and binding in osteoblast enriched cell cultures from fetal rat parietal bone. Proc Natl Acad Sci USA 85, 5889-5893

Chen CF, Kuachi H, Fujita $Y$, Terakawa N, Mikake A, Tanizawa O (1988) Changes in epidermal growth factor and its messenger ribonucleic acid levels in human placenta and isolated trophoblast cells during pregnancy. $J$ Clin Endocrinol Metab 67, 1171-1177

Cohen S (1962) Isolation of a mouse submaxillary gland protein accelerating incisor eruption and eyelid opening in the newborn animal. J Biol Chem 237, 1555-1562

Cohen S, Carpenter G (1975) Human epidermal growth factor: isolation and chemical and biological properties. Proc Natl Acad Sci USA 72, 1317-1321

Dodeur $M$, Malassiné $A$, Bellet $D$, Mensier $A$, Evain Brion D (1990) Characterization and differentiation of human first trimester placenta trophoblastic cells in culture. Reprod Nutr Dev 30, 183-190

Evain Brion D, Binet E, Anderson WB (1981) Alterations in calcitonin and parathyroid hormone responsiveness of adenylate cyclase in $\mathrm{F} 9$ embryonal carcinoma cells treated with retinoic acid and dibutyryl cAMP. J Cell Physiol 109, 453-459

Feinman MA, Kliman HJ, Caltabiano S, Strauss III JF (1986) 8-bromo-3', 5'-adenosine monophosphate stimulates the endocrine activity of human cytotrophoblasts in culture. J Clin Endocrinol Metab 63, 1211-1217

Hoshina M, Boothby M, Boime I (1982) Cytological localization of chorionic gonadotropin and placental lactogen mRNAs during development of the human placenta. $J$ Cell Biol 93, 190-198

Hsu SM, Raine L (1981) Protein A, avidin and biotin in immunochemistry. $J$ Histochem $\mathrm{Cy}$ tochem $29,1349-1353$
Huot RI, Foidart JM, Nardone RM, Stomberg K (1981) Differential modulation of human chorionic gonadotropin secretion by epidermal growth factor in normal and malignant placental cultures. J Clin Endocrinol Metab 53, 1059-1063

Jaillard C, Chatelain P, Saez JM (1987) In vitro regulation of pig Sertoli cell growth and function: effects of fibroblast growth factor and somatomedin C. Biol Reprod 37, 665-674

Jameson JL, Jaffe RC, Gleason SL, Habener JF (1986) Transcriptional regulation of chlorionic gonadotropin and subunit gene expression by 8-bromo-adenosine $3^{\prime} 5^{\prime}$ monophosphate. Endocrinology 119, 2560-2567

Kliman HJ, Nestler JE, Sermasi E, Sanger JM, Strauss III JF (1986) Purification, characterization, in vitro differentiation of cytotrophoblasts from human term placentae. Endocrinology 118, 1567-1582

Kliman HJ, Feinman MA, Strauss JF (1987) Differentiation of human cytotrophoblast into syncytiotrophoblast in culture. Trophoblast Res 2, 407-421

Lafond J, Auger D, Fortier J, Brunette MG (1988) Parathyroid hormone receptor in human placental syncytiotrophoblast brush border and basal plasma membranes. Endocrinology $123,2834-2840$

Lai WH, Guyda HJ (1984) Characterization and regulation of epidermal growth factor receptors in human placental cell cultures. J Clin Endocrinol Metab 58, 344-352

Liapi C, Gerbaud P, Anderson WB, Evain Brion D (1987) Altered hormonal responses: markers for embryonal carcinoma stem cells and their differentiated derivatives. J Cell Physiol $133,405-408$

Martin GR (1980) Teratocarcinomas and mammalian embryogenesis. Science 209, 768776

Maruo T, Matsuo H, Oishi T, Hayashi M, Nishino R, Mochizuki M (1987) Induction of differentiated trophoblast function by epidermal growth factor. Relation of immunohistochemically detected cellular epidermal growth factor receptor levels. J Clin Endocrinol Metab 64, 744-750

Menon KMJ, Jaffe RB (1973) Chorionic gonadotropin sensitive adenylate cyclase in hu- 
man term placenta. $J$ Clin Endocrinol Metab 36, 1104-1109

Milewich L, Hendricks TS, Graham JE, Gant NF, Schwartz BE, Mac Donald PC (1982) Adenylate cyclase from term human placenta and its regulation. Placenta 3, 165-180

Mirlesse V, Alsat E, Fondacci C, Evain Brion D (1990) Epidermal growth factor receptors in cultured human trophoblast cells from first and third trimester placenta. Horm Res (in press)

Nissenson RA, Arnaud CD (1979) Properties of parathyroid hormone receptor adenylate cyclase system in chicken renal plasma membranes. J Biol Chem 254, 1469-1475

Nulsen JC, Woolkalis MJ, Kopf GS, Strauss III JF (1988) Adenylate cyclase in human cytotrophoblasts: characterization and its role in modulating human chorionic gonadotropin secretion. J Clin Endocrinol Metab 66, 258265

Orloff JJ, Wu TL, Stewart AF (1989) Parathyroid hormone like proteins: biochemical responses and receptor interactions. Endocr Rev 10, 476-495

Ozturk M, Bellet DH, Manil L, Hennen G, Frydman R, Wands J (1987) Physiological studies of human chorionic gonadotropin (hCG), $\alpha$ hCG and $\beta$ hCG as measured by specific monoclonal immunoradiometric assays. Endocrinology 120, 549-558

Patillo RA, Gey GO (1968) The establishment of a cell line of human hormone synthesizing trophoblastic cells in vitro. Cancer Res 28, $1231-1236$
Patillo RA, Ruckert A, Hussa R, Bernstein R, Delfs $E$ (1971) The JAR cell line continous human multihormone production and controls. In Vitro 6, 398-402

Rodda CP, Kubota M, Heath JA, Ebeling PR, Moseley JM, Care AD, Caple IW, Martin TJ (1988) Evidence for a novel PTH related protein in fetal lamb parathyroid glands and sheep placenta. J Endocrinol 117, 261-265

Silve CM, Hardeck GT, Jones AL, Arnaud CD (1982) Parathyroid hormone receptor in intact embryonic chicken bone; characterization and cellular localization. J Cell Biol 94, 379-386

Simpson ER, Mac Donald PC (1981) Endocrine physiology of placenta. Ann Rev Physiol 43, 163-188

Steiner AL, Parker CW, Kipnis DM (1972) Radioimmunoassay of cyclic nucleotides. $J$ Biol Chem 247, 1106-1113

Truman P, Ford HC (1986) The effect of substrate and epidermal growth factor on human placental trophoblast cells in culture. In Vitro Cell Dev Biol 22, 525-528

Ulloa-Aguirre A, August AM, Golos TG, Kao LC, Sakuragi N, Kliman HJ, Strauss III JF (1987) 8 bromo-adenosine $3^{\prime}, 5^{\prime}$ monophosphate regulates expression of chorionic gonadotropin and fibronectin in human cytotrophoblasts. J Clin Endocrinol Metab 64, 10021009

Valentine-Braun KA, Northup JK, Hollenberg MD (1986) Epidermal growth factor (urogastrone) mediated phosphorylation of a $35 \mathrm{kDa}$ substrate in human placental membranes. Proc Natl Acad Sci USA 83, 236-240 